\title{
Importance of Herba Passiflorae in Medicinal Applications: Review on Experimental and Clinical Pharmacology
}

\author{
Khaled Mohamed Mohamed Koriem 1,* (D) \\ 1 Department of Medical Physiology, Medical Research Division, National Research Centre, 33 El-Buhouth Street, Dokki, \\ Cairo, 12622, Egypt \\ * Correspondence: kkoriem@yahoo.com;
}

Scopus Author ID 24477156100

Received: 23.12.2020; Revised: 20.01.2021; Accepted: 23.01.2021; Published: 31.01.2021

\begin{abstract}
The dried aerial parts of Passiflora incarnate L. plant are called Herba Passiflorae. This plant belongs to the Passifloraceae family. This review aims to focus on the importance of Herba Passiflorae in medicinal applications with special reference to its experimental and clinical pharmacology. Herba Passiflorae possesses flavonoids and alkaloids ingredients. The major constituents of Herba Passiflorae are flavonoids such as vicenin-2, orientin, isoorientin, vitexin, and isovitexin. Herba Passiflorae is applied for the cure of dysmenorrhoea, neuralgia, and nervous tachycardia. It is a slight sedative for nervous restlessness, insomnia, and anxiety. The fruit of Herba Passiflorae is used for jams, jellies, and desserts. The juice is a favorite flavoring in drinks. The pharmacology effect of Herba Passiflorae includes experimental and clinical pharmacology. Experimental pharmacology includes analgesic, antipyretic, anti-inflammatory, antimicrobial, cardiovascular, central nervous system depressant, and uterine stimulant effects. Clinical pharmacology includes anxiolytic, analgesic, and sedative effects, as well as its effect on nausea, menopause, dysmenorrhea, and diabetes. Herba Passiflorae stimulates uterine contractions, so it is used during pregnancy. The water extract of Herba Passiflorae is not genotoxic. The passion fruit is more appropriate for children's use due to the incorporation of Lactobacillus casei in passion fruit. The daily oral intake of passion fruit at public doses is non-toxic and safe. The daily dose in adults as a sedative is $0.5-2 \mathrm{~g}$ of aerial parts 3-4 times. In conclusion, Herba Passiflorae has analgesic, antipyretic, antiinflammatory, antimicrobial, cardiovascular, central nervous system depressant, uterine stimulant, anxiolytic, analgesic, and sedative effects, as well as, its effect on nausea, menopause, dysmenorrhea, and diabetes.
\end{abstract}

Keywords: Herba Passiflorae; Passiflora incarnate L.; Passifloraceae; Pharmacology; Dose.

(C) 2021 by the authors. This article is an open-access article distributed under the terms and conditions of the Creative Commons Attribution (CC BY) license (https://creativecommons.org/licenses/by/4.0/).

\section{Introduction}

The dried aerial parts of Passiflora incarnate L. plant are called Herba Passiflorae. This plant belongs to the Passifloraceae family [1-3]. There are many other names of Herba Passiflorae such as Granadilla incarnata Medik, Passiflora kerii Spreng, Apricot vine, Passiflora, passion vine, passiflora roja, water lemon, passiflore, rose-colored passionflower, wild passion flower, white passion flower [2,4]. The treatment of Passiflora caerulea with a higher concentration of Trichoderma consortium causes larger leaves, increased number and size of chloroplasts, recovery of plant physiological features, and an increase of plant crop [5]. 
The Passiflora incarnate plant is globally known as maypop. It is a perennial vine with climb or trail stems. The genus Passiflora is one member of the passionflower.

The maypop has big, complex flowers with projecting styles and stamens. It is distributed in North America [6,7]. The passion fruits grow in the rainy season, especially in the disturbing landscapes of coffee plantations, so some latency is needed for concentrated crops. The passion for fruit diversity is useful as a valuable adaptation combined with rapid growth in the commercial cultivars [8]. The cucumber mosaic virus infection affected the contents of Passiflora edulis phytochemicals and injured the development of Passiflora edulis. At the same time, Passiflora edulis develops resistance to cucumber mosaic virus stress by increasing the levels of secondary metabolites and the effects of the antioxidant enzymes [9]. The plants are grown in the full sun, and they need direct sunlight for at least 12 hours/day.

The stems are smooth or pubescent, and they are long and trailing, possessing many tendrils. Flowers are solitary, large, with long white peduncles, with a triple crown of purple and pink. Fruits are ovate berries with many ovoid, flattened seeds that have a yellowish or brownish aril [6]. Stems are green, greyish-green, or brownish, with a diameter of less than 5 $\mathrm{mm}$. This diameter may be rounded or longitudinal striated and often hollow. The Passiflora cincinnata stem extract possesses the main quantity of total polyphenols $(45.53 \mathrm{mg}$ gallic acid/g), while the maximum total flavonoid ingredients $(1.42 \mathrm{mg}$ of quercetin/g) occur in the leaf extract of the plant [10]. The plant leaves are alternate with furrowed, usually twisted petioles, have 2 nectaries at the top; palmate has 3-5 lanceolate lobes covered with few hairs on the bottom; margin indent; lamina long $=6-15 \mathrm{~cm}$, widespread, green to brownish green in color. The plant flowers diameter $=5-9 \mathrm{~cm}$ possess peduncles to reach to $8 \mathrm{~cm}$ long, rising in leaf axils; 5 in number, white, elongated petals; calyx of 5 thick sepals, upper surface green with a spine-like extension; have 3 pointed bracts with papillose margins; 5 large stamens, connect with the base and bond with the androgynophor; the ovary is greyish-green in color, higher on the top; style hairy have 3 elongated stigmatic branches. The plant fruits are $4-5 \mathrm{~cm}$ long, oval, firmed, and greenish-brown, have many seeds long $=4-6 \mathrm{~mm}$, seeds wide $=3-4$ $\mathrm{mm}$, and seeds thick $=2 \mathrm{~mm}$, with a brownish-yellow, pitted surface [2]. The leaf growth, physiological characters, and secondary metabolite of Passiflora species are improved for commercial production through light control technology. This technology is applied to leaf to produce a stable industrial supply of high leaf yields and metabolite contents [11]. The powdered plant materials are light green and have traces of leaf epidermis with graceful cell walls and anomocytic stomata; many lonely or grouped fibers from the stems have pockmarked vessels and tracheids; uniseriate trichomes with 1-3 thin-walled cells, straight or rounded and forms a hook shape. The plant flowers possess the papillose epidermis of the petals and appendages. The mature fruits have brown tannin cells, which gave the fruits their brownishyellow in color [3].

This review focuses on the phytochemical screening, chemical structure, traditional use, pharmacological effect, and the oral dose of Herba Passiflorae.

\section{Chemical Structure of Herba Passiflorae}

Passiflora incarnata plant possesses flavonoids and alkaloid ingredients [12] where the plant leaves have the highest flavonoids. The other flavonoids that occur in Passiflora incarnata include chrysin, apigenin, luteolin, quercetin, kaempferol, and isovitexin [13]. The addition of Acaulospora longula into Passiflora edulis increases leaf vitexin by $86 \%$, total phenols by $10.29 \%$, and total tannins by $13.78 \%$ [14]. The Passiflora edulis F. flavicarpa leaf 
extract contains the flavonoids (vicenin-2, orientin, isoorientin, vitexin, and isovitexin) [15]. The fermentation improves the bioactivity of Passiflora ligularis fruit by-products. Only fermented flours have a protocatechuic acid antioxidant compound with application in food, cosmetic, and pharmaceutical industries [16]. The alkaloids include the indole alkaloid harmaline, which inhibits the monoamine oxidase A enzyme. It contains lower than $1.5 \%$ of the total flavonoids (vitexin) detected by spectrophotometry and the high-performance liquid chromatography analysis [3, 17]. The Passiflora incarnate contains phenolic compounds, flavonoids, and saponins [18]. Passiflora tripartite contains 82 polar compounds, e.g., phenolic acid derivatives, organic acids, benzophenones, flavan-3-ols, flavonols, and flavones. The total phenolic content $=2356 \mathrm{mg} / 100 \mathrm{~g}$, the bound phenolic portion $=37.7 \%$ of total quantities. Flavan-3-ols, e.g., (epi)catechin, (epi)azfelechin, and their products, are the main phenolic compounds. The phenolic acids are the richest bound phenolic compounds [19]. The Passiflora edulis has piceatannol and resveratrol compounds. These compounds are useful in the cosmetic and pharmaceutical industries due to their antioxidant and anti-aging effects [20].

\section{Major chemical constituents of Herba Passiflorae}

The major constituents are flavonoids (above $2.5 \%$ ). The main ingredients are $C$ glycosyl of apigenin and luteolin. The mono- $C$-glucosyl products such as isovitexin (above $0.32 \%$ ), iso-orientin and their $2 "-\beta$-d-glycosides, and di- $C$-glycosyl products such as schaftoside (above $0.25 \%$ ), isoschaftoside (above $0.15 \%$ ), and swertisin $[1,21,22$ ). There are di- $C$-glucosyl products such as vicenin- 2 and lucenin- 2 , and few amounts of mono- $C$-glucosyl products such as orientin and vitexin in the plant [1]. Other chemical ingredients such as maltol (3-hydroxy-2-methyl- $\gamma$-pyrone) (0.05\%), chrysin, and cyanogenic glycoside (gynocardin). Few amounts of indole ( $\beta$-carboline) alkaloids (such as harman, harmol, harmine) are detected in the source plants [4, 5, 7, 22]. The Passiflora contains 9 different methyl salicylates [23]. Isoorientin, orientin, and isovitexin were isolated from passion fruit by applying solid-liquid technique followed by analyte quantification using high-performance liquid chromatography [19]. The Passiflora contains 2 biomarkers (vitexin and isovitexin) as major compounds with percentages $=0.17$ to $0.55 \%$, respectively in addition to salicin biomarker [24].

\section{Herba Passiflorae usage in traditional medicine}

As an anodyne, anti-spasmodic, slight stimulant. It is used in the treatment of dysmenorrhoea, neuralgia, and nervous tachycardia [1]. 600 species of the genus Passiflora can be used safely. The Passiflora species have health benefits, but clinical trials are still scarce [25]. Internally, it is a slight sedative for nervous restlessness, insomnia, and anxiety, being used to treat gut complications of nervous origin [1,4]. The passionflower has sedative effects that are used traditionally in Europe [12]. Passion flower occurs in European and British Pharmacopoeias to refer to the plant's dried aerial parts. In North and South America, Herba Passiflorae tea is used as a tonic [12]. The Passiflora alata or passion fruit possesses antitumor effect in vitro and in vivo with low toxicity such as declines body mass and food consumption. It increases spleen mass and histopathology of the white pulp of the spleen. It increases the number of total leukocytes. It changes the percentage of lymphocytes and neutrophils [26]. 


\section{Herba Passiflorae in the food industry}

The fruit of Herba Passiflorae is used for jams, jellies, and desserts. The juice is a favorite flavoring in drinks. It is used as a fresh substitute for its commercially grown South American relative, Passiflora edulis, a related species with similar-sized fruit. The fruit is eaten due to its slightly sweet-tart taste and a pleasant scent when fully ripe. Garcia et al. [27] produced alternative flour (30\% of passion fruit peel flour) from agro-industrial waste with potential as an ingredient for the nutritional enrichment of dietary foods. The Passiflora edulis Sims (passion fruit) seeds are applied as by-products during juice processing. The seeds are of great commercial importance in the food and cosmetics industries due to their rich polyphenols, especially piceatannol [28]. The Passiflora cincinnata is applied in coalho cheese production (a traditional Brazilian product) [29].

\section{Pharmacology effect of Herba Passiflorae}

\subsection{Experimental pharmacology.}

6.1.1. analgesic and antipyretic effects.

The dose of $5 \mathrm{~g} / \mathrm{kg}$ body weight (bw) of a $60 \%$ ethanol extract of Herba Passiflorae/day during 3 weeks in animals did not decline the pain in the tail-flick test, and no decline in body temperature also [30]. The dose of a 30\% ethanol extract of Herba Passiflorae declines to writhe in animals, a median effective dose of $1.9 \mathrm{ml} / \mathrm{kg}$ bw [31]. Passiflora incarnata induced a significant increment in the total sleep time. This increase was due to a jump in the time spent by animals in slow movement sleep. At the same time, a significant decrease in sleeplessness was observed. On the contrary, the time consumed in quick eye movement sleep decreased because its occurrence and mean duration decreased [32].

\subsubsection{Anti-inflammatory effect.}

The intragastric administration of $75-500 \mathrm{mg} / \mathrm{kg}$ bw of Herba Passiflorae ethanol extract to animals declines inflammation 1 hour after Herba Passiflorae intake [33]. Herba Passiflorae possesses anti-inflammatory and anti-oxidative effects to prevent and treat many diseases such as complex inflammatory processes [34]. The dose of $500 \mathrm{mg} / \mathrm{kg}$ bw of Herba Passiflorae ethanol extract to animals declines by $16-20 \%$ the granulomas volume caused by cotton pellets' implantation [34]. A decline by $40 \%$ in total leukocyte passage to animal pleural cavity was observed after a dose of $500 \mathrm{mg} / \mathrm{kg}$ bw of Herba Passiflorae ethanol extract. This result was due to the decrease of polymorphonuclear and mononuclear leukocyte migration. This results were comparable with $250 \mathrm{mg} / \mathrm{kg}$ bw of acetylsalicylic acid [33].

\subsubsection{Antimicrobial effect.}

The $50 \%$ ethanol extract above $500 \mathrm{mg} / \mathrm{ml}$ of Herba Passiflorae did not suppress the following fungi' growth: Botrytis cinerea, Aspergillus fumigatus, Rhizopus nigricans, Fusarium oxysporum, Penicillium digitatum, and Candida albicans [35]. Herba Passiflorae methanol extract decreased Helicobacter pylori's growth, at a minimum inhibitory concentration of $50 \mu \mathrm{g} / \mathrm{ml}$ [36]. The ethyl ester of Passiflora edulis is applied in the treatment of Chromobacterium violaceum (Gram-negative and anaerobic bacterium) associated with unmanageable human infections [37]. The water extract of Passiflora cincinnata possesses an 
inhibitory effect against Listeria spp. and multidrug-resistant Staphylococcus aureus, and slight inhibitory effect against lactic acid bacteria [29]. The seeds of passion fruit yield volatile compounds toxic to 1-octanol and Meloidogyne incognita. These compounds have a nematicidal effect against Meloidogyne incognita [38].

\subsubsection{Cardiovascular effect.}

In vitro study, animal heart treated with a $30 \%$ ethanol extract of Herba Passiflorae increased the heart muscle contraction force. The dose of $0.05 \mathrm{ml} / \mathrm{kg}$ bw of Herba Passiflorae extract did not affect animals' blood pressure [31]. Passiflora setacea administration declined insulin while increased high-density lipoprotein levels. The interleukin (IL)-17A level is unchanged after Passiflora setacea administration. The nutrigenomic studies revealed 1327 differentially expressed genes after Passiflora setacea administration, with modified genes that occurred in inflammation, cell adhesion, or cytokine-cytokine receptor. So, Passiflora setacea administration prevents cardiometabolic diseases [39].

\subsubsection{Central nervous system depressant effect.}

Intraperitoneal injection of $25 \mathrm{mg} / \mathrm{kg}$ bw of Herba Passiflorae water extract to animals declined locomotor movement and organization. Additionally, the above-mentioned dose of Herba Passiflorae to animals did not decline motor movement [40]. The dose of $60-250 \mathrm{mg} / \mathrm{kg}$ bw of a $30 \%$ ethanol or $40 \%$ ethanol extract to animals decline locomotor movement. The dose of $60 \mathrm{mg} / \mathrm{kg}$ bw of the $40 \%$ ethanol extract prolonged the sleeping time, and the dose of of 50 $\mathrm{mg} / \mathrm{kg}$ bw declined the start of seizures [41]. The effects of water extract or $30 \%$ ethanol extract of Herba Passiflorae were evaluated in animals using the conflict test, the light/dark box choice procedure, and the staircase test. The doses of $100 \mathrm{mg} / \mathrm{kg} \mathrm{bw}, 200 \mathrm{mg} / \mathrm{kg} \mathrm{bw}, 400 \mathrm{mg} / \mathrm{kg}$ bw, or $800 \mathrm{mg} / \mathrm{kg}$ bw were used compared with control administrated normal saline. The water extract declined motor movement in both staircase and free exploratory tests after intake of 400 $\mathrm{mg} / \mathrm{kg}$ and $800 \mathrm{mg} / \mathrm{kg}$ of Herba Passiflorae. The water extract also prolonged sleep. The 30\% Herba Passiflorae ethanol extract without any effect in these tests increases the animals' movement, having an anxiolytic effect at the $400 \mathrm{mg} / \mathrm{kg}$ dose [42]. The dose of $160-250 \mathrm{mg} / \mathrm{kg}$ bw of water extract of Herba Passiflorae to animal mice declined convulsions, increased sleeping time, and declined motor movement [43]. The dose of a 30\% ethanol extract of Herba Passiflorae, equal to $5 \mathrm{~g} / \mathrm{kg}$ bw/ day for 3 weeks to rats, did not affect body weight, rectal temperature, tail-flick, or motor organization. Additionally, the treated animals confirmed declined in motor movement. The electroencephalographic factors were unchanged in the treated animals [30]. The dose of $800 \mathrm{mg} / \mathrm{kg}$ bw of Herba Passiflorae ethanol extract to animals did not affect locomotor movement but without extend sleeping time [44]. In vitro study, the chrysin possesses a high affinity for the benzodiazepine receptors and declines locomotor movement in animals after the dose of $30 \mathrm{mg} / \mathrm{kg}$ bw [45, 46]. With the same dose, the chrysin increased pentobarbital-caused hypnosis [46].

\subsubsection{Uterine stimulant effect.}

The water extract of Herba Passiflorae $(1 \mathrm{~mol} / \mathrm{l})$ stimulates strong contractions in animals' uterus (not pregnant) in vitro [42]. Moreover, Herba Passiflorae water extract (1-2 $\mathrm{mol} / \mathrm{l}$ ) did not arouse contractions in the isolated uterus from pregnant animals [47]. 
6.2. Clinical pharmacology.

\subsubsection{Anxiolytic effect.}

Herba Passiflora contains vitexin (a flavonoid with anxiolytic and antidepressant effects). The arbuscular mycorrhizal fungi (AMF) increase in the production of vitexin in the leaf in response to the inoculation with AMF. This result has a great impact on the pharmaceutical industry. It enables the production of yellow Herba Passiflora with an anxiolytic effect [48]. The Passiflora edulis extract (50 and $100 \mathrm{mg} / \mathrm{kg}$ ) possesses antidepressant effect [15]. Passiflora incarnata is used in clinical applications to treat mood, anxiety, and sleep disorders (which resemble common psychiatric disorders) [49]. Passionflower modifies the treatment of benzodiazepines in hospitalized psychiatric patients in 3,252 in-house psychiatric patients through 3.5 years [50]. Passiflora incarnata $(500 \mathrm{mg})$ was orally administered 60 min before the surgery in 200 volunteers in a clinical trial. There are no significant differences in heart rate, blood pressure, and oxygen saturation were observed. Hence, passiflora incarnata organizes an herbal medicine with an anxiolytic effect [51]. In a clinical study, 5 pregnant females who possess depression or anxiety used Passiflora incarnata. The results revealed that 1 pregnancy presented neonatal death, 2 pregnancies with premature rupture of membranes, 2 infants with meconium aspiration syndrome, and 1 infant with persistent pulmonary hypertension. No congenital disabilities and no growth or developmental abnormalities for the live-born infants were reported at 6 months of age [52]. Passiflora tenuifila K. decreases locomotor activity that indicates a sedative and anxiolytic activity but does not cause muscle relaxation. Passiflora tenuifila K. (400 mg/kg) has a protective effect against pentylenetetrazole-induced seizures, declines the severity, and does not induce animal death. So, Passiflora tenuifila K. has no acute toxicity and had an anxiolytic agent, hypnotic-sedative, and anticonvulsant [53]. Passiflora incarnata L. increases in the expression of brain-derived neurotrophic factor levels. So, Passiflora incarnata L. has metabolomics and proteomic profiles [54].

\subsubsection{Analgesic effect.}

Passiflora incarnata L. has anxiolytic and sedative effects. It possesses anxiolytic, sedative, antitussive, anti-asthmatic, and antidiabetic effects. The plant has a good safety outline [12]. Passiflora incarnata affects behavior, emotions, and other problems of addicts, decreasing withdrawal symptoms, so it can be effective in controlling deprivation, decreasing dependency creation, and detoxification of opioid addicts [55]. The analgesic effect of Passiflora incarnate is similar in its effect to Cupressus sempervirens in its effect [56]. The Passiflora subpeltata Ortega declines both neutrophil infiltration and the myeloperoxidase enzyme levels. Passiflora subpeltata Ortega controls the enzymatic antioxidants such as superoxide dismutase, catalase, glutathione, and lipid peroxidation. Passiflora subpeltata Ortega extract declined nitric oxide and tumor necrosis factor- $\alpha$ production. So, Passiflora subpeltata Ortega treats inflammatory bowel disease [57].

\subsection{3. effect on nausea.}

In a clinical study, a 34-year-old female developed severe nausea, vomiting, drowsiness, and incidences of ventricular tachycardia after administration of Passiflora incarnata L., at therapeutic doses. So, Passiflora incarnata had adverse effects in this patient 
[58]. Passiflora incarnate induces optical and hearing illusions, locomotor ataxia, nausea, vomiting, misperception, and anxiety due to $\beta$-carboline alkaloids (harmaline, harmine, and tetrahydroharmine), which stimulate the central nervous system by declining amine neurotransmitters metabolism [59]. In the clinical study, the passionflower is active in refining resilience in patients who have nervous restlessness [60].

\subsection{4. effect on menopause.}

In a clinical study between 1994 and 2016, Passiflora incarnate is active in acute menopausal syndrome treatment with various mechanisms. Passiflora incarnate plays an imperative role in the treatment of acute menopausal syndrome [61]. Passiflora incarnate relieves the side effects of hot flashes. Hot flashes are the most common symptoms practiced by women through menopause. Therefore, Passiflora incarnate is a suitable treatment for women experiencing hot flashes [62]. The passionflower is used to treat anxiety symptoms and disorders in premenstrual symptoms or peri-menopausal, which is accompanied by anxiety and insomnia [63]. Passiflora incarnata L. is useful for treating generalized anxiety disorder, anxiety, insomnia, neuralgia, nervousness, opiate withdrawal, convulsion, spasmodic asthma, palpitations, and cardiac irregularities hypertension, sexual dysfunction, and menopause [64]. Passiflora is effective in relieving the peri-menopausal symptoms in women. The decline of women's vasomotor symptoms after Passiflora is due to improve their sexual life [65].

\subsection{5. effect on dysmenorrhea.}

In Brazil, Passiflora incarnata L. is applied as wormicidal, anti-spasmodic, analgesic, anti-asthmatic, and sedative agents. In Iraq, it is applied as a narcotic and sedative agent. In Turkey, it is applied for the treatment of insomnia, dysmenorrhoea, epilepsy, neurosis, and neuralgia. In Poland, it is applied to cure neurasthenia and hysteria. It is used in America, to treat dysmenorrhoea, neuralgia, diarrhea, hemorrhoids burns, and insomnia. It is used to cure patients with opiate dependence in India [12]. Passiflora incarnata have been used in menstrual disorders for centuries. It reduces menstrual pain. It declines pain sensitivity and other neuronal symptoms of dysmenorrhea. So, Passiflora incarnata declines both pelvic pain and neuronal symptoms [66].

\subsection{6. effect on diabetes.}

After 8 weeks of yellow passion fruit intake, there are no significant variances in capillary blood glucose, fasting blood glucose, and glycated hemoglobin between the study groups. So, yellow passion did not recover the glycemic control of type 2 diabetes [67]. Passiflora suberosa L. contains alkaloids, unsaturated sterols, triterpenes, saponins, flavonoids, tannins, and proanthocyanidins. Leaves Carbohydrate is $12.97 \%$. The higher hypoglycemic effect was found after $4 \mathrm{~h}$ of 50 and $100 \mathrm{mg} / \mathrm{kg}$ water leaf extract intake. The extract declined fasting blood glucose levels by $18 \%$ and declined by $79 \%$. It jumps glycogen levels in the liver by $61 \%$ and in the skeletal muscles by $57 \%$. It decreased the levels of total cholesterol by $17 \%$ and tri-glyceraldehyde levels by $12 \%$. The plant did not reveal any toxic effects. Consequently, Passiflora suberosa leaves are used to control blood glucose and cholesterol levels [68]. The diabetic rats administered with hydroethanolic extract $70 \%$ from Passiflora edulis leaf improve glycemic control, decline glycation collagen, and levels of nonhigh-density lipoprotein cholesterol, total cholesterol and creatinine, secretion of oxidant 
species, and aggregation in platelet compared with diabetic rats. So, Passiflora edulis leaf extract possesses health benefits to diabetes and stopping diabetic problems [69]. The passion fruit possesses significant effects on glycemic control [70]. The water and ethanol extracts of Passiflora ligularis Juss. (125 mg/kg to $500 \mathrm{mg} / \mathrm{kg}$, respectively) decline glycemia and jump the hepatic and muscular glycogen content. So, water and ethanol extracts of Passiflora ligularis Juss. leaves are used for the treatment or prevention of diabetes [71]. The yellow passion fruit possesses a decline in both glycemia and serum triglyceride levels [72]. The leaves of Passiflora edulis Sims have a wound-healing effect. It excites the antioxidant defense system to have a favorable effect during the treatment of skin lesions in diabetic rats, especially in the first few days after wounding. So, Passiflora edulis Sims is applied in the treatment of wounds [73]. The yellow passion fruit has an antioxidant effect. Yellow passion fruit administration declines the body weight and fat deposition (especially in the liver) and recovers glucose tolerance and insulin sensitivity in metabolic changes. Passiflora edulis intake stops insulin and glucose resistance, hepatic steatosis, and adiposity [74]. The Passiflora tripartite has antioxidant and hypoglycemic effects that are higher than for other fruits [19].

\subsubsection{Sedative effect.}

Passionflower possesses a sedative effect [50]. Water extract from the aerial parts from Passiflora incarnata L. is applied as herbal sedatives. The sedative effect of Passiflorae herba is confirmed by much evidence. The anxiolytic effect of the plants is proved. The Passiflora extracts are applied in the phytotherapy of tenseness, restlessness, and irritability [75]. The passion flower administration jumps the total sleep time. The Sleep adeptness and wake after sleep onset recovers following 2 weeks of passionflower intake. So, the passionflower effectively affects sleep parameters in adults with insomnia disorder [76]. Passiflora incarnate L. has sedative and antianxiety effects [77]. The passiflora extract possesses no effect on sleep latency, even at a dose of $3000 \mathrm{mg} / \mathrm{kg}$. No significant effect was observed on total times of wakefulness, non-rapid eye movement (non-REM) sleep, and REM sleep. No significant effects were observed with passiflora extract on delta activity during non-REM sleep [78]. The Passiflora incarnata L. possesses a significant jump on the brain-derived neurotrophic factor (BDNF) expression levels [54]. The active principles of passionflower increase the inhibitory effect of benzodiazepines binding to the gamma-aminobutyric acid receptors, causing severe secondary effects [79]. In a clinical study, 5 patients possess altered consciousness after administration with fruit from Passiflora incarnata for insomnia and restlessness. It has an intoxicating and sedative effect [80]. The Passiflora tenuifila fruit has a significant decline in locomotor effect due to sedative and anxiolytic effect but Passiflora tenuifila fruit does not induce muscle relaxation. The dose of $400 \mathrm{mg} \mathrm{kg}$ possesses a protective effect against pentylenetetrazole-induced seizures, decreasing their severity and not induce animal death [53].

\section{Toxicology}

The oral dose of a 30\% ethanol extract of Herba Passiflorae in mice was $37 \mathrm{ml} / \mathrm{kg} \mathrm{bw}$ [31]. Toxicity in animals of water extract was occurred following $900 \mathrm{mg} / \mathrm{kg} \mathrm{bw}$ intake [41]. There is no acute toxicity in animals until the dose of $500 \mathrm{mg} / \mathrm{kg} \mathrm{bw}$ or $900 \mathrm{mg} / \mathrm{kg} \mathrm{bw} \mathrm{[41,} \mathrm{81].}$ The Passiflora edulis leaf extract at a dose of $200 \mathrm{mg} / \mathrm{kg} /$ day for 90 days has a health benefit to the diabetic case, stopping the appearance of diabetes problems [69]. 


\section{Adverse effects}

There is hypersensitivity with cutaneous vasculitis and urticarial after in one case intake of Herba Passiflorae extract tablets [82]. The intake of Herba Passiflorae accompanied with IgE-facilitated occupational asthma and rhinitis in another case [83]. The passionflower possesses an anxiolytic effect. At the same time, passionflower aid men in sexual arousal and overcomes premature ejaculation and psychogenic erectile dysfunction [84]. A single case of Herba Passiflorae causing severe nausea, vomiting, drowsiness, prolonged question test segment, and incidents of ventricular tachycardia following intake of Herba Passiflorae [60]. Passiflora incarnata declines anxiety levels, and this effect is less in people with slight anxiety symptoms. There is no adverse effect such as memory loss or collapse of psychometric functions [85]. The Passiflora edulis intake declines the body weight and fat deposition (especially in the liver). It recovers the glucose tolerance and insulin sensitivity in metabolic changes. Passiflora edulis administration stops insulin and glucose resistance, hepatic steatosis, and adiposity [74].

\section{Contraindications}

Herba Passiflorae stimulates uterine contractions in animal models [40]. Its use is, therefore, contraindicated during pregnancy.

\section{Precautions}

10.1. Carcinogenesis, mutagenesis, and impairment of fertility.

There is not any genotoxic effect of Herba Passiflorae water extract until the concentration of $1.3 \mathrm{mg} / \mathrm{ml}$ in Aspergillus nidulans. This test is done in a plating method that enables the determination of somatic segregation due to chromosome mal-segregation, mitotic crossing-over, and clastogenic effects. There is no jump in the segregant sectors/colony rate at any tested dose [86]. The Passiflora mollissima seeds possess an anti-proliferative effect, so Passiflora mollissima seeds are applied to treat HT-29 carcinoma cells [87]. The anti genotoxicity of Herba Passiflorae is similar in its effect to that of anise oil [88].

10.2. Pregnancy and non-teratogenic effects.

Herba Passiflorae stimulates uterine contractions in animal models [40], so it is used as a contraindicated agent during pregnancy.

10.3. Nursing mothers.

The Herba Passiflorae is not applied by nursing mothers without advice from healthcare practitioners.

10.4. Paediatric use.

The Herba Passiflorae is not intaken to children without referring by a healthcare practitioner. Passion fruit is more appropriate for children's use than chocolate fermented milk drink due to the incorporation of Lactobacillus casei in passion fruit [89]. 


\subsection{Other precautions.}

No data established on common securities or securities related to drug interfaces, drug and laboratory method interfaces, or teratogenic effects in pregnancy by Herba Passiflorae. The blue passionflower has a neuroprotective effect against epilepsy through the relief of oxidative stress [90].

\section{Dose of Herba Passiflorae}

The daily oral intake of passion fruit at public doses is non-toxic and safe. Passiflora edulis has a great economic important crop globally. It is applied as fresh juice or food additives or health care, or medicines products [91]. This dose includes capsules, water extract, powdered dried aerial parts, extracts, or tinctures [4]. It stores in a securely closed bottle avoiding heat and light. The daily dose (in adults: as a sedative $=0.5-2 \mathrm{~g}$ of aerial parts 3-4 times $=2.5 \mathrm{~g}$ of aerial parts (as a drink) 3-4 times $=1-4 \mathrm{ml}$ tincture (1:8) 3-4 times $=$ other equivalent preparations accordingly [2]. The Passiflora caerulea (oral dose $=100$ and $200 \mathrm{mg} / \mathrm{kg}$ ) once a day for 15 days declines both the onset of convulsions and duration of clonic convulsions. So, Passiflora caerulea has an anticonvulsant effect, recovers cognitive function, declines the oxidative damage, and jumps the cholinergic neurotransmission [92]. The dose of 200 and 400 $\mathrm{mg} / \mathrm{kg}$ of Passiflora tenuifila has a protective effect against pentylenetetrazole-induced seizures. It declines the locomotor activity and possesses sedative and anxiolytic activity without causes muscle relaxation $[53,57]$.

\section{Conclusions}

The dried aerial parts of Passiflora incarnate L. plant are called Herba Passiflorae. This plant belongs to the Passifloraceae family. The major constituents of Herba Passiflorae are flavonoids. Herba Passiflorae is applied for the cure of dysmenorrhoea, neuralgia, and nervous tachycardia. The fruit of Herba Passiflorae is used for jams, jellies, and desserts. The juice is a favorite flavoring in drinks. The pharmacology effect of Herba Passiflorae includes experimental and clinical pharmacology. The water extract of Herba Passiflorae was not genotoxic. Herba Passiflorae stimulates uterine contractions in animal models, so it is used as an agent during pregnancy. Herba Passiflorae stimulates uterine contractions, so it is used during pregnancy. The water extract of Herba Passiflorae is not genotoxic. The passion fruit is more appropriate for children's use due to incorporating Lactobacillus casei in passion fruit. The daily oral intake of passion fruit at public doses is non-toxic and safe. The daily dose in adults as a sedative is $0.5-2 \mathrm{~g}$ of aerial parts 3-4 times.

\section{Funding}

This research received no external funding.

\section{Acknowledgments}

This research has no acknowledgment.

\section{Conflicts of Interest}

The author declares no conflict of interest. 


\section{References}

1. Bradley, P.R. ed. British herbal compendium, Vol. 1. Bournemouth, British Herbal Medicine Association: 1992.

2. Pharmacopoeia, B.H. British Herbal Medicine Association: Exeter. UK: 1996.

3. European Pharmacopoeia, C. European Pharmacopoeia: Supplement; Council of Europe: 2001.

4. Wichtl, M.; Bisset, N.G. Herbal Drugs and Phytopharmaceuticals, Med. Pharm Scientific Publ. Stuttgart 1994.

5. Şesan, T.E.; Oancea, A.O.; Ştefan, L.M.; Mănoiu, V.S.; Ghiurea, M.; Răut, I.; Constantinescu-Aruxandei, D.; Toma, A.; Savin, S.; Bira, A.F. Effects of Foliar Treatment with a Trichoderma Plant Biostimulant Consortium on Passiflora caerulea L. Yield and Quality. Microorganisms 2020, 8, 123, https://doi.org/10.3390/microorganisms8010123.

6. Heber, W.Y.; Youngken, H.W. Textbook of Pharmacognosy. McGraw-Hill Book Co., New Yerk: 1950.

7. Bruneton, J. Pharmacognosy, phytochemistry, medicinal plants; Lavoisier publishing: 1995.

8. Castillo, N.R.; Melgarejo, L.M.; Blair, M.W. Seed Structural Variability and Germination Capacity in Passiflora edulis Sims f. edulis. Frontiers in Plant Science 2020, 11, 498, https://doi.org/10.3389/fpls.2020.00498.

9. Lan, H.; Lai, B.; Zhao, P.; Dong, X.; Wei, W.; Ye, Y.; Wu, Z. Cucumber mosaic virus infection modulated the phytochemical contents of Passiflora edulis. Microb. Pathog. 2020, 138, 103828, https://doi.org/10.1016/j.micpath.2019.103828.

10. Leal, A.E.B.P.; de Oliveira, A.P.; Santos, R.F.d.; Soares, J.M.D.; Lavor, E.M.d.; Pontes, M.C.; Lima, J.T.d.; Santos, A.D.d.C.; Tomaz, J.C.; Oliveira, G.G.d.; Neto, F.C.; Lopes, N.P.; Rolim, L.A.; Almeida, J.R.G.d.S. Determination of phenolic compounds, in vitro antioxidant activity and characterization of secondary metabolites in different parts of Passiflora cincinnata by HPLC-DAD-MS/MS analysis. Nat. Prod. Res. 2020, 34, 995-1001, https://doi.org/10.1080/14786419.2018.1548445.

11. Ni, Y.-W.; Lin, K.-H.; Chen, K.-H.; Wu, C.-W.; Chang, Y.-S. Flavonoid Compounds and Photosynthesis in Passiflora Plant Leaves under Varying Light Intensities. Plants 2020, 9, 633, https://doi.org/10.3390/plants9050633.

12. Miroddi, M.; Calapai, G.; Navarra, M.; Minciullo, P.L.; Gangemi, S. Passiflora incarnata L.: ethnopharmacology, clinical application, safety and evaluation of clinical trials. J. Ethnopharmacol. 2013, 150, 791-804, https://doi.org/10.1016/j.jep.2013.09.047.

13. Dhawan, K.; Dhawan, S.; Sharma, A. Passiflora: a review update. J. Ethnopharmacol. 2004, 94, 1-23, https://doi.org/10.1016/j.jep.2004.02.023.

14. de Oliveira, P.T.F.; dos Santos, E.L.; da Silva, W.A.V.; Ferreira, M.R.A.; Soares, L.A.L.; da Silva, F.A.; da Silva, F.S.B. Use of mycorrhizal fungi releases the application of organic fertilizers to increase the production of leaf vitexin in yellow passion fruit. J. Sci. Food Agric. 2020, 100, 1816-1821, https://doi.org/10.1002/jsfa.10197.

15. Alves, J.S.F.; Silva, A.M.d.S.; da Silva, R.M.; Tiago, P.R.F.; de Carvalho, T.G.; de Araújo Júnior, R.F.; de Azevedo, E.P.; Lopes, N.P.; Ferreira, L.D.S.; Gavioli, E.C. In Vivo Antidepressant Effect of Passiflora edulis f. flavicarpa into Cationic Nanoparticles: Improving Bioactivity and Safety. Pharmaceutics 2020, 12, 383, https://doi.org/10.3390/pharmaceutics12040383.

16. Santos, T.R.J.; Feitosa, P.R.B.; Gualberto, N.C.; Narain, N.; Santana, L.C.L.A. Improvement of bioactive compounds content in granadilla (Passiflora ligularis) seeds after solid-state fermentation. Food Sci. Technol. Int. 2020, 1082013220944009, https://doi.org/10.1177/1082013220944009.

17. Schmidt, P.C.; González Ortega, G. Passionsblumenkraut-Bestimmung des Gesamtflavonoidgehaltes von Passiflorae herba. Dtsch. Apoth. Ztg. 1993, 133, 17-28.

18. da Silva Francischini, D.; Lopes, A.P.; Segatto, M.L.; Stahl, A.M.; Zuin, V.G. Development and application of green and sustainable analytical methods for flavonoid extraction from Passiflora waste. BMC Chemistry 2020, 14, 56, https://doi.org/10.1186/s13065-020-00710-5.

19. Giambanelli, E.; Gómez-Caravaca, A.M.; Ruiz-Torralba, A.; Guerra-Hernández, E.J.; Figueroa-Hurtado, J.G.; García-Villanova, B.; Verardo, V. New Advances in the Determination of Free and Bound Phenolic Compounds of Banana Passion Fruit Pulp (Passiflora tripartita, var. Mollissima (Kunth) LH Bailey) and Their In Vitro Antioxidant and Hypoglycemic Capacities. Antioxidants 2020, 9, 628, https://doi.org/10.3390/antiox9070628. 
20. Krambeck, K.; Oliveira, A.; Santos, D.; Pintado, M.M.; Baptista Silva, J.; Sousa Lobo, J.M.; Amaral, M.H. Identification and Quantification of Stilbenes (Piceatannol and Resveratrol) in Passiflora edulis By-Products. Pharmaceuticals 2020, 13, 73. https://doi.org/10.3390/ph13040073.

21. Qimin, L.; van den Heuvel, H.; Delorenzo, O.; Corthout, J.; Pieters, L.A.C.; Vlietinck, A.J.; Claeys, M. Mass spectral characterization of C-glycosidic flavonoids isolated from a medicinal plant (Passiflora incarnata). Journal of Chromatography B: Biomedical Sciences and Applications 1991, 562, 435-446, https://doi.org/10.1016/0378-4347(91)80597-6.

22. Meier, B. Passiflora incarnata L.-Passion flower: Portrait of a medicinal plant. Zeitschrift Phytother 1995, 16, 115-126.

23. Carlin, S.; Masuero, D.; Guella, G.; Vrhovsek, U.; Mattivi, F. Methyl Salicylate Glycosides in Some Italian Varietal Wines. Molecules 2019, 24, 3260, https://doi.org/10.3390/molecules24183260.

24. Flores, I.S.; Martinelli, B.C.B.; Lião, L.M. High-resolution magic angle spinning nuclear magnetic resonance (HR-MAS NMR) as a tool in the determination of biomarkers of Passiflora-based herbal medicines. Fitoterapia 2020, 142, 104500, https://doi.org/10.1016/j.fitote.2020.104500.

25. Fonseca, L.R.d.; Rodrigues, R.d.A.; Ramos, A.d.S.; da Cruz, J.D.; Ferreira, J.L.P.; Silva, J.R.d.A.; Amaral, A.C.F. Herbal Medicinal Products from Passiflora for Anxiety: An Unexploited Potential. The Scientific World Journal 2020, 2020, 6598434, https://doi.org/10.1155/2020/6598434.

26. Amaral, R.G.; Gomes, S.V.F.; Andrade, L.N.; Dos Santos, S.A.; Severino, P.; de Albuquerque Júnior, R.L.C.; Souto, E.B.; Brandão, G.C.; Santos, S.L.; David, J.M. Cytotoxic, antitumor and toxicological profile of Passiflora alata leaf extract. Molecules 2020, 25, 4814, https://doi.org/10.3390/molecules25204814.

27. Garcia, M.V.; Milani, M.S.; Ries, E.F. Production optimization of passion fruit peel flour and its incorporation into dietary food. Food Sci. Technol. Int. 2020, 26, 132-139, https://doi.org/10.1177/1082013219870011.

28. Pan, Z.-H.; Ning, D.-S.; Fu, Y.-X.; Li, D.-P.; Zou, Z.-Q.; Xie, Y.-C.; Yu, L.-L.; Li, L.-C. Preparative Isolation of Piceatannol Derivatives from Passion Fruit (Passiflora edulis) Seeds by High-Speed Countercurrent Chromatography Combined with High-Performance Liquid Chromatography and Screening for $\alpha$ Glucosidase Inhibitory Activities. J. Agric. Food Chem. 2020, 68, 1555-1562, https://doi.org/10.1021/acs.jafc.9b04871.

29. Costa, C.F.; Fusieger, A.; Andretta, M.; Camargo, A.C.; Carvalho, A.F.; Menezes, D.R.; Nero, L.A. Potential use of passion fruit (Passiflora cincinnata) as a biopreservative in the production of coalho cheese, a traditional Brazilian cheese. J. Dairy Sci. 2020, 103, 3082-3087, https://doi.org/10.3168/jds.2019-17791.

30. Sopranzi, N.; De Feo, G.; Mazzanti, G.; Tolu, L. [Biological and electroencephalographic parameters in rats in relation to Passiflora incarnata L.]. La Clinica terapeutica 1990, 132, 329-333.

31. Leslie, G.B. A pharmacometric evaluation of nine Bio-Strath herbal remedies. Medita 1978, 8, 3-19.

32. Guerrero, F.A.; Medina, G.M. Effect of a medicinal plant (Passiflora incarnata L) on sleep. Sleep Science 2017, 10, 96, https://doi.org/10.5935/1984-0063.20170018.

33. Borrelli, F.; Pinto, L.; Izzo, A.A.; Mascolo, N.; Capasso, F.; Mercati, V.; Toja, E. Anti-inflammatory activity of Passiflora incarnata L. in rats. Phytotherapy Research (United Kingdom) 1996.

34. Marcin, O.; Tomasz, M.K. Extracts and Flavonoids of Passiflora Species as Promising Anti-inflammatory and Antioxidant Substances. Curr. Pharm. Des. 2020, 26, 1-24, http://dx.doi.org/10.2174/1381612826666200526150113.

35. Guerin, J.C.; Reveillere, H.P. Antifungal activity of plant extracts used therapeutically. II. Study of 40 extracts on 9 fungal strains. 1985. Ann Pharm Fr 1985, 43, 77-81.

36. Mahady, G.B.; Pendland, S.L.; Stoia, A.; Hamill, F.A.; Fabricant, D.; Dietz, B.M.; Chadwick, L.R. In Vitro susceptibility of Helicobacter pylori to botanical extracts used traditionally for the treatment of gastrointestinal disorders. Phytother. Res. 2005, 19, 988-991, https://doi.org/10.1002/ptr.1776.

37. Venkatramanan, M.; Sankar Ganesh, P.; Senthil, R.; Akshay, J.; Veera Ravi, A.; Langeswaran, K.; Vadivelu, J.; Nagarajan, S.; Rajendran, K.; Shankar, E.M. Inhibition of Quorum Sensing and Biofilm Formation in Chromobacterium violaceum by Fruit Extracts of Passiflora edulis. ACS Omega 2020, 5, 25605-25616, https://doi.org/10.1021/acsomega.0c02483.

38. Silva, M.F.; Campos, V.P.; Barros, A.F.; Terra, W.C.; Pedroso, M.P.; Gomes, V.A.; Ribeiro, C.R.; Silva, F.J. Volatile emissions of watercress (Nasturtium officinale) leaves and passion fruit (Passiflora edulis) seeds against Meloidogyne incognita. Pest Manage. Sci. 2020, 76, 1413-1421, https://doi.org/10.1002/ps.5654.

39. Duarte, I.d.A.E.; Milenkovic, D.; Borges, T.K.d.S.; Rosa, A.J.d.M.; Morand, C.; Oliveira, L.d.L.d.; Costa, A.M. Acute Effects of the Consumption of Passiflora setacea Juice on Metabolic Risk Factors and Gene Expression Profile in Humans. Nutrients 2020, 12, 1104, https://doi.org/10.3390/nu12041104. 
40. Ruggy, G.H.; Smith, C.S. A pharmacological study of the active principle of passiflora incarnata. J. Am. Pharm. Assoc. 1940, 29, 245-249, https://doi.org/10.1002/jps.3030290602.

41. Speroni, E.; Billi, R.; Mercati, V.; Boncompagni, E.; Toja, E. Sedative effects of crude extract of Passiflora incarnata after oral administration. Phytother. Res. 1996.

42. Soulimani, R.; Younos, C.; Jarmouni, S.; Bousta, D.; Misslin, R.; Mortier, F. Behavioural effects of Passiflora incarnata L. and its indole alkaloid and flavonoid derivatives and maltol in the mouse. J. Ethnopharmacol. 1997, 57, 11-20, https://doi.org/10.1016/S0378-8741(97)00042-1.

43. Speroni, E.; Minghetti, A. Neuropharmacological activity of extracts from Passiflora incarnata. Planta Med. 1988, 54, 488-491, https://doi.org/10.1055/s-2006-962525.

44. Della Loggia, R.; Tubaro, A.; Redaelli, C. Evaluation of the activity on the mouse CNS of several plant extracts and a combination of them. Riv. Neurol. 1981, 51, 297-310.

45. Medina, J.H.; Paladini, A.C.; Wolfman, C.; de Stein, M.L.; Calvo, D.; Diaz, L.E.; Peña, C. Chrysin (5,7-diOH-flavone), a naturally-occurring ligand for benzodiazepine receptors, with anticonvulsant properties. Biochem. Pharmacol. 1990, 40, 2227-2231, https://doi.org/10.1016/0006-2952(90)90716-X.

46. Speroni, E.; Billi, R.; Perellino, N.C.; Minghetti, A. Role of chrysin in the sedative effects of Passiflora incarnata L. Phytotherapy Research (United Kingdom) 1996.

47. Pilcher, J.; Mauer, R. The action of "female remedies" on intact uteri of animals. Surg. Gynecol. Obstet. 1918, 27, 97-99.

48. de Oliveira, P.T.F.; dos Santos, E.L.; da Silva, W.A.V.; Ferreira, M.R.A.; Soares, L.A.L.; da Silva, F.A.; da Silva, F.S.B. Production of biomolecules of interest to the anxiolytic herbal medicine industry in yellow passionfruit leaves (Passiflora edulis f. flavicarpa) promoted by mycorrhizal inoculation. J. Sci. Food Agric. 2019, 99, 3716-3720, https://doi.org/10.1002/jsfa.9598.

49. Sarris, J.; Panossian, A.; Schweitzer, I.; Stough, C.; Scholey, A. Herbal medicine for depression, anxiety and insomnia: a review of psychopharmacology and clinical evidence. Eur. Neuropsychopharmacol. 2011, 21, 841-860, https://doi.org/10.1016/j.euroneuro.2011.04.002.

50. Keck, M.E.; Nicolussi, S.; Spura, K.; Blohm, C.; Zahner, C.; Drewe, J. Effect of the fixed combination of valerian, lemon balm, passionflower, and butterbur extracts (Ze 185) on the prescription pattern of benzodiazepines in hospitalized psychiatric patients-A retrospective case-control investigation. Phytother. Res. 2020, 34, 1436-1445, https://doi.org/10.1002/ptr.6618.

51. da Cunha, R.S.; Amorim, K.S.; Gercina, A.C.; de Oliveira, A.C.A.; dos Santos Menezes, L.; Groppo, F.C.; Souza, L.M.A. Herbal medicines as anxiolytics prior to third molar surgical extraction. A randomized controlled clinical trial. Clin. Oral Investig. 2020, 1-8, https://doi.org/10.1007/s00784-020-03468-1.

52. Ozturk, Z.; Kalayci, C.C. Pregnancy outcomes in psychiatric patients treated with passiflora incarnata. Complement. Ther. Med. 2018, 36, 30-32, https://doi.org/10.1016/j.ctim.2017.11.008.

53. Holanda, D.K.R.; Wurlitzer, N.J.; Dionisio, A.P.; Campos, A.R.; Moreira, R.A.; de Sousa, P.H.M.; de Brito, E.S.; Ribeiro, P.R.V.; Iunes, M.F.; Costa, A.M. Garlic passion fruit (Passiflora tenuifila Killip): Assessment of eventual acute toxicity, anxiolytic, sedative, and anticonvulsant effects using in vivo assays. Food Res. Int. 2020, 128, 108813, https://doi.org/10.1016/j.foodres.2019.108813.

54. Gonulalan, E.M.; Nemutlu, E.; Bayazeid, O.; Koçak, E.; Yalçın, F.N.; Demirezer, L.O. Metabolomics and proteomics profiles of some medicinal plants and correlation with BDNF activity. Phytomedicine 2020, 74, 152920, https://doi.org/10.1016/j.phymed.2019.

55. Ebrahimie, M.; Bahmani, M.; Shirzad, H.; Rafieian-Kopaei, M.; Saki, K. A review study on the effect of Iranian herbal medicines on opioid withdrawal syndrome. J. Evid. Based Complementary Altern. Med. 2015, 20, 302-309, https://doi.org/10.1177/2156587215577896.

56. Koriem, K.M.M.; Gad, I.B.; Nasiry, Z.K. Protective effect of Cupressus sempervirens extract against indomethacin-induced gastric ulcer in rats. Interdiscip. Toxicol. 2015, 8, 25-34, https://doi.org/10.1515/intox2015-0006.

57. Shanmugam, S.; Thangaraj, P.; dos Santos Lima, B.; Trindade, G.G.G.; Narain, N.; Mara de Oliveira e Silva, A.; Santin, J.R.; Broering, M.F.; Serafini, M.R.; Quintans-Júnior, L.J.; Antunes de Souza Araújo, A. Protective effects of flavonoid composition rich P. subpeltata Ortega. on indomethacin induced experimental ulcerative colitis in rat models of inflammatory bowel diseases. J. Ethnopharmacol. 2020, 248, 112350, https://doi.org/10.1016/j.jep.2019.112350.

58. Fisher, A.A.; Purcell, P.; Le Couteur, D.G. Toxicity of Passiflora incarnata L. J. Toxicol.: Clin. Toxicol. 2000, 38, 63-66, https://doi.org/10.1081/CLT-100100919. 
59. Frison, G.; Favretto, D.; Zancanaro, F.; Fazzin, G.; Ferrara, S.D. A case of $\beta$-carboline alkaloid intoxication following ingestion of Peganum harmala seed extract. Forensic Sci. Int. 2008, 179, e37-e43, https://doi.org/10.1016/j.forsciint.2008.05.003.

60. Gibbert, J.; Kreimendahl, F.; Lebert, J.; Rychlik, R.; Trompetter, I. Improvement of Stress Resistance and Quality of Life of Adults with Nervous Restlessness after Treatment with a Passion Flower Dry Extract. Complementary Medicine Research 2017, 24, 83-89, https://doi.org/10.1159/000464342.

61. Kargozar, R.; Azizi, H.; Salari, R. A review of effective herbal medicines in controlling menopausal symptoms. Electronic physician 2017, 9, 5826, https://doi.org/10.19082/5826.

62. Ghazanfarpour, M.; Sadeghi, R.; Abdolahian, S.; Roudsari, R.L. The efficacy of Iranian herbal medicines in alleviating hot flashes: A systematic review. International Journal of Reproductive BioMedicine 2016, 14 , 155.

63. Lakhan, S.E.; Vieira, K.F. Nutritional and herbal supplements for anxiety and anxiety-related disorders: systematic review. Nutr. J. 2010, 9, 42, https://doi.org/10.1186/1475-2891-9-42.

64. Appel, K.; Rose, T.; Fiebich, B.; Kammler, T.; Hoffmann, C.; Weiss, G. Modulation of the $\gamma$-aminobutyric acid (GABA) system by Passiflora incarnata L. Phytother. Res. 2011, 25, 838-843, https://doi.org/10.1002/ptr.3352.

65. Caruso, S.; Cianci, S.; Cariola, M.; Fava, V.; Rapisarda, A.M.C.; Cianci, A. Effects of nutraceuticals on quality of life and sexual function of peri-menopausal women. J. Endocrinol. Invest. 2017, 40, 27-32, https://doi.org/10.1007/s40618-016-0500-2.

66. Gomathy, N.; Dhanasekar, K.; Trayambak, D.; Amirtha, R. Supportive therapy for dysmenorrhea: Time to look beyond mefenamic acid in primary care. 2019, 8, 3487-3491, https://doi.org/10.4103/jfmpc.jfmpc_717_19.

67. de Araújo, M.F.M.; Veras, V.S.; de Freitas, R.W.J.F.; de Paula, M.d.L.; de Araújo, T.M.; Uchôa, L.R.A.; Gaspar, M.W.G.; Cunha, M.d.C.d.S.O.; Serra, M.A.A.d.O.; Carvalho, C.M.d.L.; Costa, E.C.; Damasceno, M.M.C. The effect of flour from the rind of the yellow passion fruit on glycemic control of people with diabetes mellitus type 2: a randomized clinical trial. Journal of Diabetes \& Metabolic Disorders 2017, 16, 18, https://doi.org/10.1186/s40200-017-0300-z.

68. Sudasinghe, H.P.; Peiris, D.C. Hypoglycemic and hypolipidemic activity of aqueous leaf extract of Passiflora suberosa L. PeerJ 2018, 6, e4389, https://doi.org/10.7717/peerj.4389.

69. Salles, B.C.C.; da Silva, M.A.; Taniguthi, L.; Ferreira, J.N.; da Rocha, C.Q.; Vilegas, W.; Dias, P.H.; Pennacchi, P.C.; da Silveira Duarte, S.M.; Rodrigues, M.R. Passiflora edulis leaf extract: evidence of antidiabetic and antiplatelet effects in rats. Biol. Pharm. Bull. 2020, 43, 169-174, https://doi.org/10.1248/bpb.b18-00952.

70. Danilo, F.S.; Vivian, S.V.; Vanessa, E.C.S.F.; Maria, L.P.; Maria, A.A.O.S.; Ana, C.P.J.C.; Maria da Conceição, S.O.C.; Maria, V.O.Q.; Marta, M.C.D.; Francisco, E.R.P.; Roberto, W.J.F.F.; Márcio, F.M.A. Effectiveness of Passion Fruit Peel Flour (Passiflora edulis L.) versus Turmeric Flour (Curcuma longa L.) on Glycemic Control: Systematic Review and Meta-Analysis. Curr. Diabetes Rev. 2020, 16, 450-456, http://dx.doi.org/10.2174/1573399815666191026125941.

71. Rey, D.; Fernandes, T.A.; Sulis, P.M.; Gonçalves, R.; Sepúlveda R, M.; Silva Frederico, M.J.; Aragon, M.; Ospina, L.F.; Costa, G.M.; Silva, F.R.M.B. Cellular target of isoquercetin from Passiflora ligularis Juss for glucose uptake in rat soleus muscle. Chem.-Biol. Interact. 2020, 330, 109198, https://doi.org/10.1016/j.cbi.2020.109198.

72. Sousa, D.F.d.; Araújo, M.F.M.d.; de Mello, V.D.; Damasceno, M.M.C.; Freitas, R.W.J.F.d. CostEffectiveness of Passion Fruit Albedo versus Turmeric in the Glycemic and Lipaemic Control of People with Type 2 Diabetes: Randomized Clinical Trial. J. Am. Coll. Nutr. 2020, 1-10, https://doi.org/10.1080/07315724.2020.1823909.

73. Soares, R.D.F.; Campos, M.G.N.; Ribeiro, G.P.; Salles, B.C.C.; Cardoso, N.S.; Ribeiro, J.R.; Souza, R.M.; Leme, K.C.; Soares, C.B.; de Oliveira, C.M.; Elston, L.B.; da Fonseca, C.C.P.; Ferreira, E.B.; Rodrigues, M.R.; Duarte, S.M.S.; Paula, F.B.A. Development of a chitosan hydrogel containing flavonoids extracted from Passiflora edulis leaves and the evaluation of its antioxidant and wound healing properties for the treatment of skin lesions in diabetic mice. Journal of Biomedical Materials Research Part A 2020, 108, 654662, https://doi.org/10.1002/jbm.a.36845.

74. De Faveri, A.; De Faveri, R.; Broering, M.F.; Bousfield, I.T.; Goss, M.J.; Muller, S.P.; Pereira, R.O.; de Oliveira e Silva, A.M.; Machado, I.D.; Quintão, N.L.M.; Santin, J.R. Effects of passion fruit peel flour 
(Passiflora edulis f. flavicarpa O. Deg.) in cafeteria diet-induced metabolic disorders. J. Ethnopharmacol. 2020, 250, 112482, https://doi.org/10.1016/j.jep.2019.112482.

75. Krenn, L. Die Passionsblume (Passiflora incarnata L.) - ein bewährtes pflanzliches Sedativum*. Wien. Med. Wochenschr. 2002, 152, 404-406, https://doi.org/10.1046/j.1563-258X.2002.02062.x.

76. Lee, J.; Jung, H.-Y.; Lee, S.I.; Choi, J.H.; Kim, S.-G. Effects of Passiflora incarnata Linnaeus on polysomnographic sleep parameters in subjects with insomnia disorder: a double-blind randomized placebo$\begin{array}{lllllll}\text { controlled } & \text { study. } & \text { Int } & \text { Clin. } & \text { Psychopharmacol. } & \mathbf{2 0 2 0}, & 35,\end{array}$ https://doi.org/10.1097/YIC.0000000000000291.

77. Peeters, E.; Driessen, B.; Steegmans, R.; Henot, D.; Geers, R. Effect of supplemental tryptophan, vitamin E, and a herbal product on responses by pigs to vibration. J. Anim. Sci. 2004, 82, 2410-2420, https://doi.org/10.2527/2004.8282410x.

78. Shinomiya, K.; Inoue, T.; Utsu, Y.; Tokunaga, S.; Masuoka, T.; Ohmori, A.; Kamei, C. Hypnotic Activities of Chamomile and Passiflora Extracts in Sleep-Disturbed Rats. Biol. Pharm. Bull. 2005, 28, 808-810, https://doi.org/10.1248/bpb.28.808.

79. Carrasco, M.C.; Vallejo, J.R.; Pardo-de-Santayana, M.; Peral, D.; Martín, M.Á.; Altimiras, J. Interactions of Valeriana officinalis L. and Passiflora incarnata L. in a patient treated with lorazepam. Phytother. Res. 2009, 23, 1795-1796, https://doi.org/10.1002/ptr.2847.

80. Solbakken, A.M.; Rørbakken, G.; Gundersen, T. Nature medicine as intoxicant. Tidsskrift for den Norske Laegeforening: Tidsskrift for Praktisk Medicin, ny Raekke 1997, 117, 1140-1141.

81. Aoyagi, N.; Kimura, R.; Murata, T. Studies on Passiflora incarnata dry extract. I. Isolation of maltol and pharmacological action of maltol and ethyl maltol. Chem. Pharm. Bull. 1974, 22, 1008-1013.

82. Smith, G.W.; Chalmers, T.M.; Nuki, G. Vasculitis Associated with Herbal Preparation Containing Passijiora Extract. Rheumatology 1993, 32, 87-88.

83. Giavina-Bianchi Jr, P.F.; Castro, F.F.M.; Machado, M.L.S.; Duarte, A.J.S. Occupational respiratory allergic disease induced by Passiflora alata and Rhamnus purshiana. Ann. Allergy, Asthma Immunol. 1997, 79, 449454.

84. Pyke, R.E. Sexual Performance Anxiety. Sexual Medicine Reviews 2020, 8, 183-190, https://doi.org/10.1016/j.sxmr.2019.07.001.

85. Janda, K.; Wojtkowska, K.; Jakubczyk, K.; Antoniewicz, J.; Skonieczna-Żydecka, K. Passiflora incarnata in Neuropsychiatric Disorders-A Systematic Review. Nutrients 2020, 12, 3894, https://doi.org/10.3390/nu12123894.

86. Ruiz, A.R.; De la Torre, R.A.; Alonso, N.; Villaescusa, A.; Betancourt, J.; Vizoso, A. Screening of medicinal plants for induction of somatic segregation activity in Aspergillus nidulans. J. Ethnopharmacol. 1996, 52, 123-127, https://doi.org/10.1016/0378-8741(96)01394-3.

87. Ballesteros-Vivas, D.; Alvarez-Rivera, G.; León, C.; Morantes, S.J.; Ibánez, E.; Parada-Alfonso, F.; Cifuentes, A.; Valdés, A. Foodomics evaluation of the anti-proliferative potential of Passiflora mollissima seeds. Food Res. Int. 2020, 130, 108938, https://doi.org/10.1016/j.foodres.2019.108938.

88. Koriem, K.M.M.; Arbid, M.S.; El-Gendy, N.F. The Protective Role of Anise Oil in Oxidative Stress and Genotoxicity Produced in Favism. J. Diet. Suppl. 2016, 13, 505-521, https://doi.org/10.3109/19390211.2015.1119775.

89. Mantovani, F.D.; de Carla Bassetto, M.; de Souza, C.H.B.; Aragon, D.C.; de Santana, E.H.W.; Pimentel, T.C.; Aragon-Alegro, L.C. Is there an impact of the dairy matrix on the survival of Lactobacillus casei Lc-1 during shelf life and simulated gastrointestinal conditions? J. Sci. Food Agric. 2020, 100, 32-37, https://doi.org/10.1002/jsfa.9988.

90. Zhang, Y.; Zhao, J.; Afzal, O.; Kazmi, I.; Al-Abbasi, F.A.; Altamimi, A.S.A.; Yang, Z. Neuroprotective role of chrysin-loaded poly(lactic-co-glycolic acid) nanoparticle against kindling-induced epilepsy through Nrf2/ARE/HO-1 pathway. J. Biochem. Mol. Toxicol. 2020, n/a, e22634, https://doi.org/10.1002/jbt.22634.

91. He, X.; Luan, F.; Yang, Y.; Wang, Z.; Zhao, Z.; Fang, J.; Wang, M.; Zuo, M.; Li, Y. Passiflora edulis: An Insight Into Current Researches on Phytochemistry and Pharmacology. 2020, 11, https://doi.org/10.3389/fphar.2020.00617.

92. Aseervatham, G.S.B.; Abbirami, E.; Sivasudha, T.; Ruckmani, K. Passiflora caerulea L. fruit extract and its metabolites ameliorate epileptic seizure, cognitive deficit and oxidative stress in pilocarpine-induced epileptic mice. Metab. Brain Dis. 2020, 35, 159-173, https://doi.org/10.1007/s11011-019-00501-5. 